\title{
42
}

\section{Simplifying Government Secrecy?}

\section{Daniel Stewart ${ }^{1}$}

\section{Introduction}

There are many legitimate reasons for governments to keep secrets. Exposing the information collected, developed or used by government can undermine a government's effectiveness, inhibiting the provision and creation of new information. Exposure can adversely affect private individuals and businesses. However, public disclosure can also subject government action to scrutiny, enhance trust, or provide a resource to be utilised for private or collective gain. Balancing the costs and benefits associated with disclosure of government information is difficult, and has led in Australia - including at the Commonwealth level - to an increasingly complex array of regulation and restriction.

This chapter demonstrates that complexity through two recent cases involving the disclosure of Commonwealth Government information by individuals working within government. The first looks at attempts to protect witnesses to conditions in Australian immigration detention centres. The second looks to the ramifications of engagement by public servants with social media. Both suggest that the possible benefits of disclosure of government information can be obscured by the risk of more immediate adverse consequences. The complexity and uncertainty of the

1 Senior Lecturer, ANU College of Law, The Australian National University. 
various forms of regulation in this area itself acts as a disincentive for government disclosure. A common framework for assessing the balance of public interests is needed.

\section{Restrictions on Government Disclosure}

Unauthorised disclosure of information that is not already publicly accessible, when relayed in circumstances implying limitations on the use or disclosure of that information, is protected by the courts through the equitable action for breach of confidence. ${ }^{2}$ However, breach of confidence applies differently when government is involved. In Commonwealth v John Fairfax \& Sons $^{3}$ the Commonwealth Government was not able to rely on confidentiality to prevent further distribution and partial newspaper serialisation of a series of diplomatic briefings and cables. Mason J declined to accept the cables were confidential, despite their classified status:

The court will not prevent the publication of information which merely throws light on the past workings of government, even if it be not public property, so long as it does not prejudice the community in other respects. Then disclosure will itself serve the public interest in keeping the community informed and in promoting discussion of public affairs. If, however, it appears that disclosure will be inimical to the public interest because national security, relations with foreign countries or the ordinary business of government will be prejudiced, disclosure will be restrained. There will be cases in which the conflicting considerations will be finely balanced, where it is difficult to decide whether the public's interest in knowing and in expressing its opinion, outweighs the need to protect confidentiality. ${ }^{4}$

The concern over public disclosure of the cables was not with their content but what the fact of release might mean for the relationship between Australia and the countries concerned. As the Secretary of the Department of Foreign Affairs at the time suggested: '[i]t is much more likely to facilitate our future relations if the government has been seen to try its utmost to prevent that [disclosure] happening. ${ }^{5}$

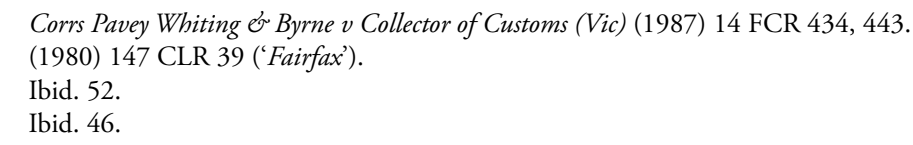


Mason J was not persuaded that 'the degree of embarrassment to Australia's foreign relations which flow from disclosure is enough to justify interim protection of confidential information' ${ }^{6}$ Confidentiality of government information depended on the possible effect on a recognised government interest outweighing the public interest in disclosure. Striking that balance continues to define the limits of government secrecy, both in terms of how it is struck, and who gets to decide.

\section{Role of Legislation}

In various ways Fairfax is a high-water mark for openness in government. The case came at a time when the traditional view of the need for government secrecy, based on the Westminster system's reliance on responsible government and a politically neutral public service, was starting to be questioned. The process of law reform in this area has meant that inherent limitations on the executive's capacity to generate and maintain secrecy have been largely overtaken by reliance on legislative authority to collect, and disclose, information. ${ }^{7}$

By the time Fairfax was decided, freedom of information legislation had already been introduced into the Commonwealth Parliament, though it would take until 1982 to be enacted. The Freedom of Information Act 1982 (Cth) (FOI Act) was meant to shift the emphasis away from executive discretion towards establishing a right of access subject only to listed categories of exceptions. In doing so it set out a range of government interests which could be used by the executive to justify withholding disclosure, expanding upon those interests considered legitimate in common law conceptions of confidentiality. ${ }^{8}$

The FOI Act was closely followed by the Archives Act 1983 (Cth), providing for the preservation and future public use of government records. A recognition of the need to maintain public trust in the way government collects, uses and stores private information also led to the

6 Ibid. 54.

7 See Daniel Stewart, 'Assessing Access to Information in Australia: The Impact of Freedom of Information Laws on the Scrutiny and Operation of the Commonwealth Government' in John Wanna, Evert Lindquist and Penelope Marshall (eds), New Accountabilities, New Challenges (ANU Press, 2015).

8 Stewart, above $\mathrm{n} 7$. 
Privacy Act 1988 (Cth). Much more recently, the Public Interest Disclosure Act 2013 (Cth) (PID Act) was introduced to augment the protection for whistleblowers to disclose wrongdoing and maladministration. ${ }^{9}$

Each of these pieces of legislation was introduced in recognition of the benefits of government disclosure of information but takes a very different approach to regulating the different interests involved. There are also a wide range of general policies, standards and guidance that impact how government agencies handle information. The National Archives of Australia has identified some 72 such instruments which, directly or indirectly, need to be considered by Commonwealth agencies and, in some cases, non-government bodies, including those that contract with government to provide services to the public. ${ }^{10}$

Subject matter specific legislation providing for the collection or use of information also plays an important role. In Re Smith Kline \& French Laboratories (Australia) Ltd and Secretary, Department of Community Services and Health, ${ }^{11}$ for example, information supplied to the government for the purposes of regulatory approval of a pharmaceutical product could be used for approval of a competitor's version of the same substance. Confidentiality was limited by the legislative objective of enhancing public health and safety.

In other circumstances the legislative context may place limits on the use and disclosure of information. In Johns v Australian Securities Commission ${ }^{12}$ the High Court stated:

A statute which confers a power to obtain information for a purpose defines, expressly or impliedly, the purpose for which the information when obtained can be used or disclosed. The statute imposes on the person who obtains information in exercise of the power a duty not to disclose the information obtained except for that purpose.

9 Note that external public interest disclosures can be made under the PID Act only in a narrow range of circumstances and usually only after an internal disclosure has been made: see Philip Moss, Independent Review of the Public Interest Disclosure Act 2013, www.dpmc.gov.au/resource-centre/ government/review-public-interest-disclosure-act-2013 (viewed 20 April 2017).

10 National Archives of Australia, Legislation, Policies, Standards and Advice and Your Agency's Accountability, August 2015, www.naa.gov.au/information-management/information-governance/ legislation-standards/index.aspx (viewed 17 May 2016).

11 (1991) 28 FCR 291.

12 (1993) 178 CLR 408. 
Identifying the purposes for which information was obtained, and the subsequent limits on further use or disclosure of that information, is therefore a statute-by-statute proposition. Even interpreting the limits of explicit provision in legislation for disclosure or, more usually, preventing disclosure, involves assessing the intended role of information disclosure in light of the context and purpose of the statute as a whole.

It is the complexity of the interaction between these multiple sources regulating disclosure of government information which gives rise to the need for reform. The effect is often to leave disclosure to the discretion of the executive. A common framework would allow more explicit reference to the public interest in government disclosure when balanced against the interests protected through individual statutes.

\section{Court Sanctioned Disclosure}

$A S v$ Minister for Immigration and Border Protection (Ruling No. 3$)^{13}$ is one of a number of class action cases relating to the conditions in immigration detention centres with which Australia is involved. This case concerned a negligence claim arising from medical treatment available on Christmas Island. An interim application was brought to protect the ability of witnesses to speak to lawyers for the plaintiffs without facing possible prosecution.

Section 42 of the Border Force Act 2015 (Cth) makes it a criminal offence for an entrusted person to record or disclose protected information. Entrusted persons include Immigration and Border Protection employees as well as a variety of persons who provide services to the department, including state, territory and foreign government employees, and government contractors and consultants. This includes medical staff at the centre. Protected information is information obtained by entrusted persons in that capacity. Under s 42(2) an offence is not committed where the record or disclosure is: authorised under various explicit circumstances, including where it is necessary to prevent or lessen serious threat to the life or health of an individual; made in the course of employment or service; required or authorised by law; or required by an order or direction of a court or tribunal. 
While s 42 has been the subject of considerable criticism, the explicit reference in that section to the making of a court order or direction enabled that court to protect voluntary disclosure by witnesses. The main concern of the Victorian Supreme Court in this matter then became how the obligations under $s 42$ related to other legislative and common law duties. Ultimately s 42 was held not to enable the court to release witnesses from other obligations or potential liabilities.

For example, s 70 of the Crimes Act 1914 (Cth) makes it an offence for Commonwealth officers, including persons performing services for or on behalf of the Commonwealth, to publish or communicate, without authority, any fact or document which they know or possess by virtue of being a Commonwealth officer and which is their duty not to disclose. Section 70 does not in itself create a duty not to disclose. That duty may arise under the Public Service Act 1999 (Cth), for example, or potentially under contractual or equitable obligations of confidentiality. It is not clear if s 70 applies to oral opinions or advice; the breadth of publication or communication seems limited only by intention; and there appears no need to demonstrate harm to any public or private interest, whether anticipated or actual. ${ }^{14}$

The uncertainty over what information might be disclosed by witnesses and which relevant duty of non-disclosure might be in issue meant that the court in $A S$ was not willing to make an order protecting witnesses from $s 70$. Similarly, while the court was willing to set aside any obligations of confidentiality which involve 'an interference with the administration of justice', the nature of the obligation and extent of that interference had to be identified with precision. Many future court hearings might be required to consider how obligations of confidentiality might arise, and be overcome.

14 Justice Susan Kenny, 'Secrecy Provisions: Policy and Practice' (Address to the National Information Law Conference in Canberra, 24 March 2011), www.alrc.gov.au/news-media/2011/ secrecy-provisions-policy-and-practice\#_ftn 48 . 


\section{Engagement With the Public through Social Media}

Starr $v$ Department of Human Services ${ }^{15}$ considered the fairness of the dismissal of a departmental employee after he had made several comments on public discussion forums including Whirlpool and Sportal. The comments were made over nearly a three year period, on his own time and on his own computer. They had come to the department's attention after several comments in which he had corrected some information posted by the department's social media unit. The department investigated and discovered earlier comments which, together with departmental records, enabled the employee to be identified. The investigation also revealed several comments where the employee had expressed his frustration at having to deal with 'junkies' and 'spastics' and 'deadbeat leeches', that a large proportion of clients were not genuine, and that processing times were disgraceful.

The Fair Work Commission found these later comments to be in breach of the APS Code of Conduct ${ }^{16}$ and various departmental policies and guidelines. ${ }^{17}$ These included obligations to avoid conflicts of interest $;{ }^{18}$ not use information or one's position to cause a detriment to the government; ${ }^{19}$ uphold APS values of ethical, respectful, accountable and impartial service and the integrity and good reputation of the Australian Public Service; ${ }^{20}$ and not disclose information obtained in connection with employment as a public servant under the Public Service Regulations 1999. ${ }^{21}$

However, the Commission also found that the penalty of dismissal was disproportionate to the gravity of $\mathrm{Mr}$ Starr's misconduct, having regard to all the circumstances including that his conduct did not affect his actual

15 [2016] FWC 1460.

16 Public Service Acts 13.

17 For example, Department of Human Services, Social Media Policy for Departmental Staff, www. humanservices.gov.au/corporate/media/social-media-department/social-media-policy-departmentalstaff (viewed 20 April 2017). See also the recently revised Australian Public Service Commission, APS Values and Code of Conduct in Practice, ss 4 and 6, www.apsc.gov.au/publications-and-media/currentpublications/values-and-conduct (viewed 20 April 2017).

18 s 13(7).

19 s 13(10).

$20 \mathrm{~s} 13(11)$ and $s 10$.

21 Which includes non-disclosure of such information if it is reasonably foreseeable that the disclosure could be prejudicial to the effective working of government', or communicated or received in confidence, unless otherwise authorised or already in the public domain: $\mathrm{r} 2.1$. 
work performance, caused no demonstrated detriment to the department, was engaged in impulsively rather than with deliberation, and consisted of a small number of widely interspersed comments over a period of years. ${ }^{22}$

In doing so the Commissioner interpreted the APS Values and Code of Conduct through the lens of the Constitutionally implied freedom of political communication:

which, to the extent necessary to maintain the effective operation of the system of representative and responsible government provided for by the Constitution, operates to preclude the exercise of legislative power to curtail the freedom. ${ }^{23}$

That meant the need for a public servant to be apolitical only restricted political comments which could compromise the ability of public servants to carry out their functions, in this case taking into account the administrative rather than political nature of their particular role. It also meant that some harm to the department would have to be demonstrated. Damaging the department's reputation for treating people with respect and impartially and fairly was such a harm. Correcting erroneous information was not.

\section{Further Reform}

The secrecy provision discussed in the case studies above are arguably relatively limited in their scope. The Australian Law Reform Commission, in its Secrecy Laws and Open Government in Australia report, ${ }^{24}$ examined some 506 secrecy provisions in 176 pieces of legislation, including 358 distinct criminal offences. The ALRC recommended repeal of $s 70$ along with the even more complex s 79 of the Crimes Act, and replacing them with a general secrecy offence for unauthorised disclosures that have a demonstrated adverse effect on the public interest through:

- harming security, defence or international relations;

- interfering with an investigation of criminal offences;

- endangering life or physical safety; or

- prejudicing public safety.

23 [2016] FWC 1460 at [72], citing Lange v Australian Broadcasting Corporation (1997) 189 CLR 520 at $559-62$.

24 Report No 112, 2010. 
In those circumstances disclosure would have to be: in the course of an officer's functions or duties; authorised by an agency head or minister by declaring that the disclosure would, on balance, be in accordance with the public interest; or already in the public domain. ${ }^{25}$

The ALRC considered more specific secrecy protection should only be enacted where necessary, and generally through an express requirement that the disclosure has caused, or was likely or intended to cause, harm to a specified public interest. A blanket protection against disclosure would be warranted only for limited categories of information, such as national security or where a relationship of trust between the government and individuals is integral for an effective regulatory system but not able to be proved in a criminal prosecution. ${ }^{26}$

The ALRC's recommendations recognise the need for a common framework in which eroding the public interest in government disclosure could be justified. Such a framework was recently discussed in McCloy $v$ State of New South Wales, ${ }^{27}$ where the protection of the implied freedom of political communication was held to involve three questions:

1. Does the law effectively burden the freedom of political communication in its terms, operation or effect?

2. Are the purposes of the law and the means adopted legitimate, in the sense they are compatible with the maintenance of the constitutionally prescribed system of representative government?

3. Is the law reasonably appropriate and adapted to advancing that legitimate purpose? In other words, is it proportional?

Proportionality in turn requires that there be no suitable and reasonably practicable alternative means of achieving the same purpose, and the importance of that purpose outweighs the extent of the restriction on communication.

As a general framework, assessing the proportionality of any legislative restriction on disclosure of government information involves a value judgement of whether the particular harm caused by the disclosure in question outweighs the public benefit in disclosure. Legislation still has

25 ALRC Report 112, Recommendations 5-7.

26 Ibid. Recommendations 8-9.

27 [2015] HCA 34. 
a legitimate role in setting out the range of interests that might need protecting, but more than merely speculative evidence of the harm should be required before any particular disclosure is prevented. ${ }^{28}$

\section{Conclusion}

As the case studies set out in this paper suggest, identifying the limitations on disclosure of government information is a complex task. The uncertain operation and interaction of the various legislative and other restrictions can only act to further deter disclosure. Despite the long history or reform in this area, government disclosure often remains a matter of government discretion.

However, the general approach to government confidentiality of Mason $\mathrm{J}$ in Fairfax, reflected more recently in the approach of the ALRC and the emerging approach to proportionality in the implied freedom of political communication, suggests that a common framework is possible. Few government interests in themselves justify limiting disclosure. Other interests require identifying both the nature and extent of any adverse effect caused by the disclosure in question and considering alternative, less restrictive means to achieve government purposes. Any remaining harm has to be balanced against the benefits of disclosure. By making more explicit the values involved in that balancing of the effects of disclosure, a more developed and accepted understanding of the benefits of disclosure, now and in the future, might be realised. 
This text is taken from New Directions for Law in Australia: Essays in Contemporary Law Reform, edited by Ron Levy, Molly O’Brien, Simon Rice, Pauline Ridge and Margaret Thornton, published 2017 by ANU Press, The Australian National University, Canberra, Australia. 